\title{
Pain and injury in adolescent dancers: systematic review
}

\author{
Dor e lesões em bailarinos adolescentes: revisão sistemática
}

Andressa Melina Becker da Silva1, Sônia Regina Fiorim Enumo

DOI 10.5935/1806-0013.20160030

\section{ABSTRACT}

BACKGROUND AND OBJECTIVES: Dance is not a sport but, for having competitions, requires requires a good physical conditioning, which may induce pain, which, in turn, may lead to injuries. During adolescence, this condition is more severe because the body is still developing. Considering the importance of studying such health-threatening condition of adolescent dancers, this study presents a systematic review of national and international literature on pain and injuries in this population, identifying type and site of pain, its evaluation, causes and therapies.

CONTENTS: By applying inclusion and exclusion criteria, 15 scientific articles published between 2005 and 2015 in national and international journals, BIREME and Academic Search Premier Databases were read in full. Studies have shown classic ballet as the most common modality. Most common painful body parts were feet and knees. Major reason for pain was movement repetition and overtraining. Several dance-induced injuries were mentioned, among them patellofemoral syndrome, patellar hypermobility and patellar subluxation, in addition to possible related factors. As pain relief therapy, indications were massage, stretching and physiotherapy; just one study has mentioned psychological intervention.

CONCLUSION: Major reason for adolescent dancers' injuries is overtraining, and most affected sites are feet and knees. Pain relief therapies are more physical than psychological.

Keywords: Adolescent, Dance, Injuries, Pain.

\section{RESUMO}

JUSTIFICATIVA E OBJETIVOS: A dança não é uma modalidade esportiva, mas, por ter competiçóes, exige muito preparo físico dos bailarinos, o que ocasiona quadros álgicos, os quais, por sua vez, levam a lesóes. $\mathrm{Na}$ adolescência, essa condição é mais grave, pois o corpo está em desenvolvimento. Conside-

1. Pontifícia Universidade Católica de Campinas, Departamento de Psicologia, Campinas, SP, Brasil.

Submitted in January 19, 2016.

Accepted for publications in April 18, 2016.

Conflict of interests: none - Sponsoring sources: CAPES; CNPq.

Correspondence to:

Av. John Boyd Dunlop, s/n - Jardim Ipaussurama

13060-904 Campinas, SP, Brasil.

E-mail: andressa_becker@hotmail.com

(C) Sociedade Brasileira para o Estudo da Dor rando a importância de estudar essa condição de risco à saúde de bailarinos na adolescência, este estudo apresenta uma revisão sistemática da literatura nacional e internacional sobre a dor e lesôes nessa população, identificando o tipo e local de dor, sua avaliação, causas e tratamentos.

CONTEÚDO: Aplicando-se critérios de inclusão e exclusão, foram lidos na íntegra, 15 artigos científicos, publicados entre 2005 e 2015 em periódicos nacionais e internacionais, nas bases de dados da BIREME e Academic Search Premier. Os estudos revelaram o ballet clássico como a modalidade mais praticada. As partes do corpo mais indicadas com dor são os pés e os joelhos. A causa principal de dor é a repetição de movimentos e o excesso de treinamento. Foram citadas diversas lesôes provocadas pela dança, apresentando, por exemplo, síndrome patelofemoral, hipermobilidade patelar e subluxação da patela, além de possíveis fatores relacionados. Como tratamentos para alívio da dor, são indicados a massagem, alongamento e fisioterapia; apenas um artigo citou a intervenção psicológica.

CONCLUSÃO: O principal motivo para lesôes em bailarinos adolescentes é o overtraining, e os lugares mais afetados são os pés e joelhos. As intervençôes na dor são de caráter mais físico do que psicológico.

Descritores: Adolescente, Dança, Dor, Lesóes.

\section{INTRODUCTION}

Dance is not a sport, however it also requires intense physical training for the dancer to reach a good performance. Another similarity with sports is competition, translated into dance festivals ${ }^{1}$. Lessons, rehearsals and competitions, when excessive, lead to psychophysiological stress, which may be noxious to health. This condition, added to lack of physical and emotional recovery, induces pain in a pattern known as "overtraining syndrome" 2 .

This situation might not be apparent, since dance has artistic character so that dancers, when interpreting a character, move lightly and smoothly, preventing people of noticing their effort and how movements generate pain ${ }^{3}$. In case of adolescent dancers, there is the aggravating factor of still being in physical development and not having enough anatomic, physiologic and morphologic maturity to stand intense training 4 .

Considering the importance of preventing pain and injuries in the population of adolescent dancers who are starting their professional lives, it is relevant to identify and analyze scientific production on pain and injuries in this population.

This study aimed at carrying out a systematic national and 
international literature review on pain in adolescent dancers, published in the last 10 years (2005-2015).

\section{CONTENTS}

This is a systematic literature review carried out in January 2016 in two major electronic databases: a) Virtual Health Library (BVS) / BIREME (Latin-American and Caribbean Center of Health Sciences Information), which contains LILACS (Latin-American and Caribbean Literature in Health Sciences), Scielo (Scientific Electronic Library On Line) and Medline (International Literature on Health Sciences) databases; and b) Academic Search Premier, which contains 4700 complete texts. The objective was to answer the following question: "Which variables associated to pain and types of injuries in adolescent dancers are studied with regard to pain causes, location and therapy"?

For such, the following inclusion criteria were applied: a) complete text; b) reviewed by peers; c) published between 2005 and 2015. Exclusion criteria were: a) literature reviews; b) repeated articles; c) non relevant (outside the objectives of the study, which had not adequately described the methodology, such as sample, tools and primary results); d) not having adolescents as participants. Descriptors were selected from BVS Health Sciences Descriptors (DeCS) being applied the following: "dor", "dança", "pain", "dance", "dolor", "danza", using the following strategy with Boolean operators: [(dor OR pain OR dolor) AND (dança OR dance OR danza)]. Figure 1 summarizes the selection process of articles.

Articles search and selection were separately performed by two researchers and results were compared at the end. Articles generating disagreement or questions were discussed to check whether they met inclusion criteria, were relevant to the subject and contemplated proposed objective. So, after

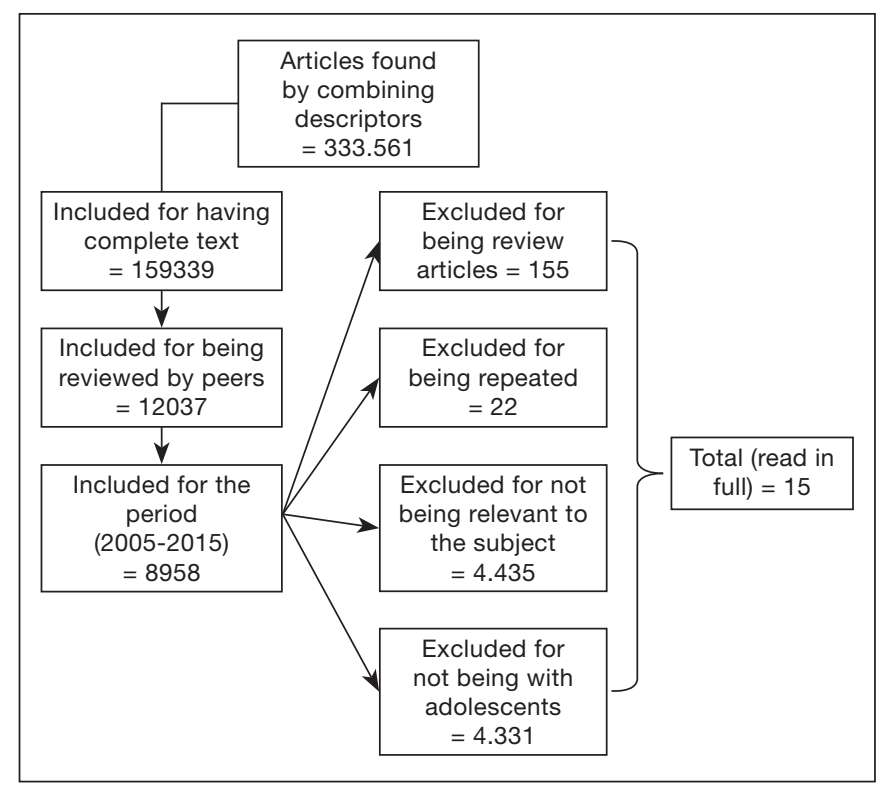

Figure 1. Selection process of articles comparison between results and discussion of disagreements and analyses, 15 articles were selected to be read in full. A data extraction card was developed with the Excel $^{\circ}$ program, with the following content: national or international article, journal where it was published, publication year, sample (number of participants, dance modality), evaluation tools, pain location and causes, types of injuries and pain therapies or interventions.

From 15 articles read in full, three were by national authors ${ }^{3,7,10}$ and 12 by international authors. Articles were published in 10 different journals, being that one of them had four publications (Journal of Dance Medicine \& Science), two journals had two publications each (Journal of Orthopaedic \& Sports Physical Therapy e Medical Problems of Performing Artists), and remaining seven journals had one publication each. The year with the largest number of publications was $2013(n=4)$ followed by $2010(n=3)$ and $2011(n=3)$.

Adding participants of all evaluated studies, final sample was of 3428 dancers, of both genders, mean age of $15 \pm 3.77$ years practicing the following dance modalities: classic ballet ( $\mathrm{n}=7$ studies); jazz, contemporary dance and Irish dance $(\mathrm{n}=4$ each); step dancing and street dance $(\mathrm{n}=2$ each); school physical education versus dance $(n=1)$. In a same study, more than one dance modality was evaluated while some studies have not identified dance modality.

\section{Pain evaluation tools for dancers}

Different tools were used to evaluate pain and investigate body injuries, namely: physical evaluation $(n=5)$; medical charts evaluation $(n=4)$; interviews $(n=3)$; X-rays $(n=2)$; Roland Morris questionnaire, to check daily life activities problems due to back pain; visual numeric scale (VNS) to evaluate pain intensity; pain numeric scale (with 11 points); Reported Condition Inquiry; Screening and On Line Questionnaire ( $\mathrm{n}=1$ each). Most of these tools are widely used by the scientific community and have proven evidences of validity and reliability.

Next, major injuries and most affected body regions, causes and therapies mentioned in the studies are described.

\section{Major injuries in dancers}

Some studies define injury as synonym for pain or musculoskeletal problems resulting from dance-related training and competitions ${ }^{7-10}$; however there is no consensus in the literature $^{11}$. Junge et al. ${ }^{12}$, for example, consider injury any type of tissue injury. It is important to highlight that each article has presented an operational definition of the term, so that there has been no confusion about what was being studied. Other studies have defined injury as we have understood, describing serious physical and psychological problems with dancers ${ }^{13-22}$.

Table 1 shows that 10 out of 15 articles reported injuries, while remaining five articles have addressed pain or other contents unrelated to injuries. Among reported injuries there are patellofemoral syndrome, patellar hypermobility and patellar subluxation, among others. 
Table 1. Results of studies on dance injuries $(n=10)$

\begin{tabular}{|c|c|c|c|}
\hline Authors & $\mathrm{n}$ & Dance modality & Studies content \\
\hline Gamboa et al. ${ }^{17}$ & 204 & Classic ballet & $\begin{array}{l}53 \% \text { of injuries were on foot or ankle, } 21.60 \% \text { on hip, } 16.10 \% \text { on knee and } 9.40 \% \text { on } \\
\text { back. Injured dancers with higher history of back pain, right foot pronation, insufficient } \\
\text { plantar flexion of right ankle and less strength on extremities as compared to non- } \\
\text {-injured dancers. }\end{array}$ \\
\hline Noon et al. ${ }^{16}$ & 69 & Irish dance & $\begin{array}{l}217 \text { injuries, being the most frequent }(29.90 \%) \text { stress fracture, followed by patellofe- } \\
\text { moral syndrome, severe conditions, ankle sprain, posterior tibial tendinitis and plantar } \\
\text { fascitis, but also with lumbosacral and pelvic injuries. }\end{array}$ \\
\hline Air e Rietveld ${ }^{21}$ & 1 & Classic ballet & $\begin{array}{l}\text { Report of a successful surgical procedure on Freiberg's disease, also called "osteone- } \\
\text { crosis of the second metatarsal head". This disease is characterized by pain, hyper- } \\
\text { sensitivity, edema and movement limitation in the metatarsal joint. }\end{array}$ \\
\hline $\begin{array}{l}\text { Kulig, Fietzer \& } \\
\text { Popovich }^{14}\end{array}$ & 12 & Classic ballet & $\begin{array}{l}\text { "Saut de chat" landing poses more risk to patellar injuries than impulse movement to } \\
\text { take off. }\end{array}$ \\
\hline Leanderson et al..$^{15}$ & 476 & Classic ballet & $\begin{array}{l}\text { Most injuries caused by repetitive movements and overtraining, being } 76 \% \text { on lower } \\
\text { limbs. Most frequent types are ankle sprains and tendinitis. }\end{array}$ \\
\hline Smith ${ }^{22}$ & 2 & $\begin{array}{l}\text { Classic ballet, jazz, } \\
\text { hip hop, contempo- } \\
\text { rary dance, step dan- } \\
\text { cing }\end{array}$ & $\begin{array}{l}\text { Report of two cases of "symptomatic accessory navicular -an extra bone located clo- } \\
\text { se to navicular bone, which may lead to increased and painful volume on inner foot". } \\
\text { Case } 1 \text { - surgical procedure; Case } 2 \text { - pain management, cryotherapy, strengthening } \\
\text { of trunk and lower limbs, exercises for movement amplitude, balance and proprio- } \\
\text { ception, training with intervals and guided progression to return to dance. Both were } \\
\text { effective. So, it is possible to treat the problem without necessarily going through a } \\
\text { surgical procedure. }\end{array}$ \\
\hline $\begin{array}{l}\text { Jenkins, Wyon \& } \\
\text { Nevill }^{18}\end{array}$ & 47 & Contemporary dance & $\begin{array}{l}\text { There is increased risk of up to } 9 \% \text { of having two or more injuries when dancers use } \\
\text { tricks to compensate external hip rotation deficits. }\end{array}$ \\
\hline Steinberg et al. ${ }^{19}$ & 1288 & - & $\begin{array}{l}23.80 \% \text { had scoliosis. Dancers with scoliosis had more anatomic abnormalities - } \\
\text { genu varus (knees apart and feet approach forming an internal angle opening) and } \\
\text { halux valgus (bunion) and had also more back injuries than the group without scoliosis. }\end{array}$ \\
\hline $\begin{array}{l}\text { Cahalan \& } \\
\text { O'Sullivan }{ }^{20}\end{array}$ & 178 & Irish dance & $\begin{array}{l}137(76.70 \%) \text { had history of foot and ankle injury. Major causes of such injuries were: } \\
\text { accidents, fatigue, repetitive movements (older dancers reported more loss of perfor- } \\
\text { mance due to injuries) and insecurity phases. }\end{array}$ \\
\hline Beasley et al. ${ }^{13}$ & 67 & Irish dance & $\begin{array}{l}86 \text { injuries, } 90.70 \% \text { on knee, related to overtraining. Among injuries: patellofemoral } \\
\text { syndrome, patellar hypermobility and patellar subluxation. }\end{array}$ \\
\hline
\end{tabular}

\section{Pain location in dancers}

There has been pain location regularity and similarity among studies. Some body parts were more frequently mentioned, such as feet and knees ( $n=8$ each), ankle $(n=7)$, followed by legs, thigh and hip ( $\mathrm{n}=3$ each), shoulders and abdomen $(\mathrm{n}=1$ each). This was expected since these are sites more involved with dance movements and, due to overtraining, are daily required by repetitive movements.

\section{Causes of pain among dancers}

With regard to causes of pain, most frequently mentioned by studies $(53.33 \%$; 8/15 studies) were the large number of repetitions and overtraining. Dancers start training early and are required to have good and excellence performance during dance festivals. This makes them increase training intensity, overloading the body, which may impair health ${ }^{3,5}$. Situation worsens when they are adolescents, with the body still being developed. Considering anatomic, morphologic and physiologic aspects, they would need smoother lessons, rehearsals and training ${ }^{4}$. Overtraining is not so studied in dance ${ }^{6}$, being best known among sportsmen ${ }^{2}$. This is explained exactly by the imbalance between training load and recovery, which is necessary for body energetic reestablishment, as well as for psychological and emotional balance ${ }^{2}$.

In addition to overtraining, other causes of pain in this population were: effort and acute and traumatic injuries ( $n=2$ each), and other common causes in dance, such as the use of Pointe shoes, hyperextension, lack of adequate joint warming, movement compensation with tricks, accidents, emotional insecurity and muscle strength imbalance ( $\mathrm{n}=1$ each). Scoliosis and symptomatic accessory navicular - extra bone located close to the navicular bone, which may lead to increased and painful volume on inner foot ( $\mathrm{n}=1$ each) were also mentioned.

\section{Handling pain by dancers}

In these studies with dancers, dealing with pain seems to be more by avoidance of the problem than by an effective search for solution. Beasley et al. ${ }^{13}$ have identified major delay of dancers before looking for a physician or other health professional after the first symptoms of pain. This is explained by the fear of being forced to stop dancing, being an indicator of physical exercise dependence, in addition to concern with financial requirements, in case of professional dancers. There 
might also be the fear of being replaced by another dancer and, slowly, loose their prominence, as well as fear that it is a severe injury which may impair health and quality of life. So, going to the physician is delayed at the utmost and they just do it when there is no other option.

It is interesting to notice also the importance given in the article by Chalan and O'Sullivan ${ }^{20}$ to pain-related psychological aspects, being the only article with this approach. Authors have identified a moderate level of psychic distress, with interpersonal difficulties and tension when relating to other people. To deal with such difficulties, in addition to psychological support, dancers have reported treating pain and injuries with massage, stretching and physiotherapy. In light of this scenario, it is noticed the importance of a psychological intervention to make dancers aware of the risk of ignoring pain ${ }^{20}$, in addition to promoting better pain coping strategies $^{23}$.

This study was limited to descriptors used for search and to inclusion and exclusion criteria. However, results are relevant for a reflection on the subject, by bringing major pain and injury sites, their causes and interventions. So, it may subsidize preventive studies. These should include symptoms screening, adequate physical and psychological support ${ }^{20,23}$ aiming at decreasing losses to health, quality of life and performance of dancers, especially during adolescence.

\section{CONCLUSION}

Overtraining is the primary reason for injuries and pain in adolescent dancers, being more prevalent on feet and knees. These are in general evaluated by physical evaluation and by checking medical records. Physiotherapeutic interventions, including massage and stretching, are more common in the area. Considering this population of adolescent dancers, it is mandatory the orientation of involved professionals, be them physical educators or dance professionals, to consider the level of motor and physiologic maturity of these dancers, in order to prevent injuries.

Psychological support is necessary since pain involves psychological mechanisms which may influence pain improvement by means of adaptive coping strategies, and also speed recovery after injury. As observed in this study, this type of intervention is less common, so that just one study has highlighted psychological aspects, showing the importance of jointly working physical and psychological aspects.
This study has shown that there are few scientific studies on pain and injuries in adolescent dancers, especially in the national literature. Even so, results are a warning for the development specificities of this age group and for the impact of pain on health and quality of life of these adolescents.

\section{REFERENCES}

1. Guarino L. Is dance a sport? A twenty-first-century debate. J Dance Educ. 2015;15(2):77-80

2. Brink MS, Visscher C, Coutts AJ, Lemmink KAPM. Changes in perceived stress and recovery in overreached young elite soccer players. Scad J Med Sci Sports. 2012;22(2):285-92.

3. Grego LG, Monteiro HL, Gonçalves A, Aragon FF, Padovani CR. Agravos músculo-esqueléticos em bailarinas clássicas, não clássicas e praticantes de educação física. Arq Ciênc Saúde. 2006;13(3):61-9.

4. Weineck J. Treinamento ideal. São Paulo: Manole; 2003.

5. Singh S. The meaning of pain during the process of embodiment: A case study of trainee modern dancers' experiences of pain. Sport Educ Soc. 2011;16(4):451-65.

6. Taylor J, Estanol E. Dance psychology for artistic and performance excellence. Champaign: Human Kinetics; 2015.

7. Campoy FA, Coelho LR, Bastos FN, Netto Júnior J, Vanderlei LC, Monteiro HL, et al. Investigation of risk factors and characteristics of dance injuries. Clin J Sport Med. 2011;21(6):493-8.

8. Stein CJ, Tyson KD, Johnson VM, Popoli DM, d'Hemecourt PA, Micheli LJ. Injuries in Irish dance. J Dance Med Sci. 2013;17(4):159-64.

9. Thomas H, Tarr J. Dancers' perceptions of pain and injury: positive and negative effects. J Dance Med Sci. 2009;13(2):51-9.

10. Aquino CF, Cardoso VA, Machado NC, Franklin JS, Augusto VG. Análise da relaçâo entre dor lombar e desequilíbrio de força muscular em bailarinas. Fisioter Mov. 2010;23(3):399-408

11. Atalaia T, Pedro R, Santos C. Definição de lesão esportiva: uma revisão da literatura. Rev Port Fis Desporto. 2009;3(2):13-21.

12. Junge A, Rosch D, Peterson L, Graf-Baummann T, Dvorak J. Prevention of soccer injuries: A prospective intervention study in youth amateur players. Am J Sports Med. 2002;30(5):652-9

13. Beasley MA, Stracciolini A, Tyson KD, Stein CJ. Knee injury patterns in young Irish dancers. Med Probl Perform Art. 2014;29(2):70-3.

14. Kulig K, Fietzer AL, Popovich JM. Ground reaction forces and knee mechanics in the weight acceptance phase of a dance leap take-off and landing. J Sports Sci. 2011;29(2):125-31

15. Leanderson C, Leandrson J, Wykman A, Strender LE, Johansson SE, Sundquist K Musculoskeletal injuries in young ballet dancers. Knee Surg Sports Traumatol Arthrosc. 2011;19(9):1531-5.

16. Noon M, Hoch AZ, McNamara L, Schimke J. Injury patterns in female Irish dancers. PMR. 2010;2(11):1030-4.

17. Gamboa JM, Roberts LA, Maring J, Fergus A. Injury patterns in elite preprofessional ballet dancers and the utility of screening programs to identify risk characteristics. J Orthop Sports Phys Ther. 2008;38(3):126-36.

18. Jenkins JB, Wyon M, Nevill A. Can turnout measurements be used to predict physiotherapist-reported injury rates in dancers? Med Probl Perform Art. 2013;28(4):230-5.

19. Steinberg N, Hershkovitz I, Peleg S, Dar G, Masharawi Y, Zeev A, et al. Morphological characteristics of the young scoliotic dancer. Phys Ther Sport. 2013;14(4):213-20.

20. Cahalan R, O'Sullivan K. Injury in professional Irish dancers. J Dance Med Sci. 2013;17(4):150-8

21. Air ME, Rietveld AB. Freiberg's disease as a rare cause of limited and painful relevé in dancers. J Dance Med Sci. 2010;14(1):32-6.

22. Smith TR. Management of dancers with symptomatic accessory navicular: 2 case reports. J Orthop Sports Phys Ther. 2012;42(5):465-73.

23. Encarnacion ML, Meyers MC, Ryan ND, Pease DG. Pain coping styles of ballet performers. J Sport Behav. 2000;23(1):20-32. 